\title{
DNA Barcoding of The Soft Coral, Clavularia inflata, Shows Two Major Groups Across Indonesian Coral Reefs
}

\author{
Beginer Subhan ${ }^{1, *}$, Dietriech G. Bengen ${ }^{1}$, Sebastian Ferse ${ }^{2,3}$, Fauzan Dzulfannazhir ${ }^{1}$, \\ Luzmi Malia Izza ${ }^{1}$, Nurlita Putri Anggraini ${ }^{1}$, Prakas Santoso ${ }^{1}$, Dondy Arafat' ${ }^{1}$, Lalu M. Iqbal Sani ${ }^{4}$, \\ Hawis Madduppa ${ }^{1,4}$
}

\author{
${ }^{1}$ Department of Marine Science and Technology, Faculty of Fisheries and Marine Science, IPB University \\ Kampus IPB Dramaga Bogor 16680 West Java, Indonesia \\ ${ }^{2}$ Leibniz Centre for Tropical Marine Research, \\ Fahrenheitstraße 6, 28359 Bremen, Germany \\ ${ }^{3}$ Department of Marine Ecology, Faculty of Biology and Chemistry, University of Bremen \\ Bibliothekstraße 1, 28359 Bremen, Germany \\ ${ }^{4}$ Oceanogen Environmental Biotechnology Laboklinikum \\ Jl. Bambu Ori 3 No. 46,Taman Yasmin Sektor 7, East Cilendek, Bogor, West Java 16112, Indonesia \\ Email: beginersubhan@apps.ipb.ac.id
}

\begin{abstract}
Clavularia inflata was first described from Ternate Island, Indonesia in 1896 and later reported appeared-from Japan and Taiwan in 1953. Clavularia (Blainville 1830) soft corals exhibit complex morphological traits that are difficult to differentiate, thus complicating their identification. DNA barcoding has been envisioned and actively pushed as a credible method for assigning unidentified specimens to known species by comparison to a molecular reference data database. DNA barcoding is an important tool to support the management of biological resources, one of which are soft corals. As soft corals are among the species that are difficult to identify morphologically, DNA barcoding data are very valuable for identifying them. Thus, the purpose of this study was to use molecular methods to confirm the identity of 25 colonies taken from 13 Indonesian coral reef sites (Anambas, Natuna, Tanjung Lesung, Kepulauan Seribu, Madura, Kangean, Bontang, Lombok, Manado, Wakatobi, Morotai, Kon, and Maluku Tenggara Barat (MTB)) and putatively identified as C. inflata. All specimens were identified as C. inflata molecularly using the mitochondrial DNA mtMuts gene. The results from this study can enrich the information base for barcoding of soft corals elsewhere because the samples were taken across a range of nearly $4000 \mathrm{~km}$ throughout Indonesia archipelago. Although a comparison of the nucleotide base chains to Genbank data indicates that the samples belong to a single species, two clades in the phylogenetic tree and data from the Automatic Barcode Gap Discovery $(A B G D)$ indicate that there are two major groups of C. inflata in Indonesia, implying cryptic species.
\end{abstract}

Keywords: Molecular taxonomy, Phylogeny, Octocorallia, DNA Barcoding

\section{Introduction}

The sub-class Octocorallia (Cnidaria: Anthozoa) contains more than 2,000 species which are spread all over the world and occur in a variety of habitats (Bayer, 1973; Fabricius and Alderslade, 2001). Octocorals have polyps with eight pinnate tentacles and internal calcareous skeletal elements, termed sclerites. The octocoral order Alcyonacea (soft corals) is the largest in number of species. The species of this order may or may not contain symbiotic algae in their tissue (they are zooxanthellate vs. azooxanthellate species, respectively). Alcyonacea are found in abundance in coral reef habitats in most of the IndoWest Pacific and play an important ecological role, often occurring in percentages of benthic substrate cover equal to or greater than that of scleractinian corals (Tursch and Tursch, 1982; Dinesen, 1983; Dai, 1988; Riegl et al., 1995; Fabricius, 1997).

There are about 96 soft coral genera belonging to 23 families in the Indo-Pacific (Fabricius and Alderslade, 2001). Manuputty (2002) notes 28 genera of soft corals in 4 families occuring in Indonesian waters, one of which is Clavularia. Clavularia (Blainville, 1830) spp., belonging to the suborder stolonifera, are zooxanthellate soft corals, with every single polyp connected to the base. Polyps can be pink to brownish gray and measure about 30 $\mathrm{mm}$ in diameter. Stolons are brown to dark red, and are often covered by algae or sponges (Fabricius and Alderslade, 2001). Clavularia inflata was first described from Ternate island, Indonesia (Schenk, 
1896). Utinomi (1953) later reported C. inflata from Japan and Taiwan.

DNA barcoding has been envisioned and widely promoted as a reliable technique by which unidentified specimens can be assigned to known species by comparison to a reference database of molecular exemplars (Hebert et al., 2003). At this time the use of DNA barcodes is widely spread because it has several advantages: (1) DNA accurately distinguishes groups that have the same morphological character (Bingpeng et al., 2018), (2) it can identify species at different stages of the developmental cycle (Hubert et al., 2010), and (3) it can be used to help identify specimens that are damaged and incomplete (Prehadi et al., 2015). Similarly, it can be used to identify material such as processed fish or shellfish found in seafood products and thus assist in the authentication of fishery products (Abdullah et al., 2020) for traceability of marine fisheries. A molecular approach has been used successfully to identify marine biota at the species level in a number of different taxa, i.e. soft corals (McFadden et al., 2006a; McFadden et al., 2009; Benahayu and McFadden 2011; Mc Fadden et al., 2014; Kusuma et al., 2016), fish (Jefri et al., 2015; Prehadi et al., 2015; Sembiring et al., 2015; Madduppa et al., 2016; Toha et al., 2020; Fadli et al., 2020; Madduppa et al., 2021), giant clams (DeBoer et al., 2008), sea squirts (Anzani et al., 2019), coral reef fish (Ackiss et al., 2013), small crustaceans (Hazeri et al., 2019), sea turtles (Madduppa et al., 2019), sponges (Madduppa et al., 2015), horse shoe crabs (Aini et al., 2020), crown-of-thorns starfish (Vogler et al., 2013), cephalopods (Kholilah et al., 2021), gastropods (Selaky et al., 2017), and sea cucumbers (Madduppa et al., 2017).

Soft coral research in Indonesia has been limited to assessing the biological aspects and distribution of soft corals (Manuputty, 2002, 2008, 2010). Phylogenetic relationships in Clavularia tropical soft corals have been studied by McFadden and Ofwegen (2012). To date, DNA barcoding has been carried out for a number of species of Clavulariidae: Clavularia borealis (Moore et al., 2017), Hanabira yukibana (Lau et al., 2019), Inconstantia procera, I. pannucea, Carijoa riisei, Arula petunia, Cornularia pabloi (Mc Fadden and Ofwegen, 2012) and Trachythela rudis (Quattrini et al., 2014).

More recently, the use of molecular identification for soft corals has also become a supporting tool in describing or determining new species (Benahayu and McFadden, 2011). The results of identification can also aid in delineating boundaries between species that have not been revealed previously (McFadden et al., 2006, 2009; France, 2007). The genetic information for marine organisms in Indonesia is still sparse (Madduppa et al., 2021). Therefore, this study aimed to apply DNA barcoding on samples putatively identified as Clavularia inflata collected from a suite of Indonesian coral reefs in order to verify species identity and assess the potential existence of cryptic species.

\section{Material and Methods}

\section{Study sites, specimen and tissue sampling}

Sampling of specimens and tissue was conducted sporadically between February and August 2018 at 13 sites (Anambas, Natuna, Tanjung Lesung, Kepulauan Seribu, Madura, Kangean, Bontang, Lombok, Manado, Wakatobi, Morotai, Kon, and Maluku Tenggara Barat; Table 1:).

Sampling was carried out using a purposive sampling approach. Purposive sampling is a nonprobability sampling technique in which the researcher selects the sample according to its presence (Etikan et al., 2016). This can reduce the risk of an insufficient number of samples. Furthermore, the selection of research sites considered the spread of Clavularia inflata in Indonesia and information from diving clubs and divers. Samples were taken from between 4 and 7 colonies at each site. A colony, referring to an individual, was defined as a discrete patch of polyps connected by stolons, and only colonies more than 3 $\mathrm{m}$ apart were sampled (Bastidas et al., 2002). A total of 25 sample mtDNA sequences were obtained from 13 locations across Indonesia coral reefs (Figure 1).

During the dive, each sample was stored in a sample tube filled with seawater. Back on board, samples were transferred into sterile sample bottles of $10 \mathrm{ml}$ volume filled with $97 \%$ ethanol. Upon arrival in the laboratory, the samples were then stored in the freezer at a temperature of $4^{\circ} \mathrm{C}$. Sampled colonies were documented before each sample was taken using a Canon G16 camera in underwater housing. For each colony, a wide-angle photo of the colony and its surrounding environment and a close-up photo were taken.

\section{Molecular analysis}

DNA was extrated from tissue samples using the gSYNC DNA Extraction Kit for Blood and Tissue from Geneaid. DNA extraction followed the standard protocol of the manufacturer, modified and optimized for the genomic DNA extraction from Clavularia inflata. Approximately $40 \mathrm{mg}$ of tissue sample were ground and put into $1.5 \mathrm{ml}$ microcentrifuge tubes, $150 \mu \mathrm{l}$ GST Buffer and $20 \mu \mathrm{l}$ Proteinase $\mathrm{K}$ were added, and the samples were then vortexed. The samples were incubated at $60^{\circ} \mathrm{C}$ over night. 


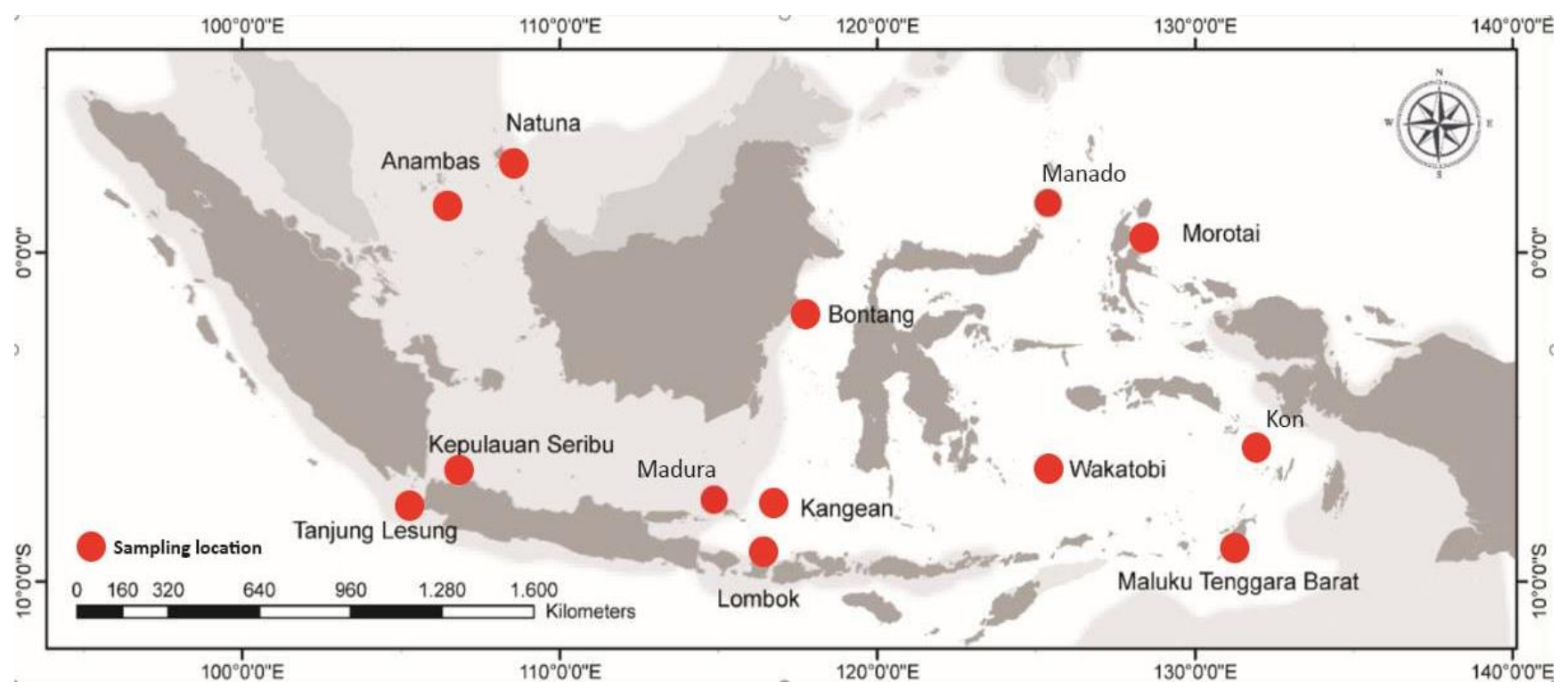

Figure 1. Sites of tissue and specimen sampling at 13 coral reef locations across Indonesia

Table 1. Sampling sites and number of samples of Clavularia inflata across Indonesian coral reefs

\begin{tabular}{lcc}
\hline \multicolumn{1}{c}{ Sampling sites } & Number of samples & Position \\
\hline Anambas & 2 & $3^{\circ} 23^{\prime} 27.2^{\prime \prime} \mathrm{N} 106^{\circ} 08^{\prime} 56.0^{\prime \prime} \mathrm{E}$ \\
Natuna & 2 & $4^{\circ} 00^{\prime} 12.1^{\prime \prime} \mathrm{N} 108^{\circ} 24^{\prime} 45.8^{\prime \prime} \mathrm{E}$ \\
Tanjung Lesung & 2 & $6^{\circ} 28^{\prime} 43^{\prime \prime} \mathrm{S} 105^{\circ} 39^{\prime} 31.3^{\prime \prime} \mathrm{E}$ \\
Kepulauan Seribu & 2 & $5^{\circ} 38^{\prime} 38.4^{\prime \prime} \mathrm{S} 106^{\circ} 33^{\prime} 25.0^{\prime \prime} \mathrm{E}$ \\
Madura & 1 & $7^{\circ} 12^{\prime} \mathrm{O} 7^{\prime \prime} \mathrm{S} 14^{\circ} 02^{\prime} 55.8^{\prime \prime} \mathrm{E}$ \\
Kangean & 2 & $6^{\circ} 50^{\prime} 33.7^{\prime \prime} \mathrm{S} 115^{\circ} 13^{\prime} 40.1^{\prime \prime} \mathrm{E}$ \\
Lombok & 2 & $8^{\circ} 43^{\prime} 25.7^{\prime \prime} \mathrm{S} 115^{\circ} 57^{\prime} 42.5^{\prime \prime} \mathrm{E}$ \\
Bontang & 2 & $0^{\circ} 04^{\prime} 40.6^{\prime \prime} \mathrm{N} 117^{\circ} 33^{\prime} 50.9^{\prime \prime} \mathrm{E}$ \\
Manado & 3 & $1^{\circ} 32^{\prime} 42.9^{\prime \prime} \mathrm{N} 124^{\circ} 48^{\prime} 55.2^{\prime \prime} \mathrm{E}$ \\
Wakatobi & 1 & $5^{\circ} 28^{\prime} 05.9^{\prime \prime} \mathrm{S} 123^{\circ} 42^{\prime} 49.2^{\prime \prime} \mathrm{E}$ \\
Morotai & 2 & $2^{\circ} 02^{\prime} 42.1^{\prime \prime} \mathrm{N} 128^{\circ} 17^{\prime} 27.4^{\prime \prime} \mathrm{E}$ \\
Kon & 2 & $3^{\circ} 55^{\prime} 26.8^{\prime \prime} \mathrm{S} 131^{\circ} 12^{\prime} 33.8^{\prime \prime} \mathrm{E}$ \\
Maluku Tenggara Barat (MTB) & 2 & $8^{\circ} 14^{\prime} 41.4^{\prime \prime S} 130^{\circ} 42^{\prime} 28.3^{\prime \prime} \mathrm{E}$ \\
\hline
\end{tabular}

Mitochondrial DNA mtMuts partial gene fragments were amplified by using ND42625F (5TACGTGGYACAATTGCTG-3) (Lepard 2003) and Mut3458R (5-TSGAGCAAAAGCCACTCC-3) (Sanchez et al., 2003). The PCR reaction was carried out in a total volume of $25 \mu \mathrm{l}$, including $12.5 \mu \mathrm{l} \mathrm{MyTaq^{ \textrm {TM } }}$ Red Mix Bioline, $10 \mathrm{mM}$ of each primer (Foward and Reverse) at a volume of $1.25 \mu \mathrm{l}, 9 \mu \mathrm{l}$ deionized water (ddH2O), and $1 \mu \mathrm{l}$ DNA template. The mixture was run in a thermal cycler by using the following PCR cycle: predenaturation at $95^{\circ} \mathrm{C}$ for 3 mins, followed by 35 cycles of denaturation at $95^{\circ} \mathrm{C}$ for $30 \mathrm{sec}$, annealing at $50^{\circ} \mathrm{C}$ for $30 \mathrm{sec}$, and extension at $72^{\circ} \mathrm{C}$ for $1 \mathrm{~min}$.

DNA product quality was checked by using an electrophoresis chamber. The $1 \%$ agarose gel and DNA dye Ethidium Bromide $(4 \mu \mathrm{l})$ were used as gel agarose media of electrophoresis. A total of $1 \mu \mathrm{l} \mathrm{PCR}$ product was loaded and inserted in agarose wells. The electrophoresis process was run using an electrophoresis machine with a voltage of $100 \mathrm{~V}$ $135 \mathrm{~V}$ and a current of $400 \mathrm{~mA}$, with a time of 35 minutes. Electrophoresis results were visually inspected using an an Alphamager Mini doc gel machine, and the photos of the results stored digitally. PCR products of sufficient quality were then sequenced by using a modified Sanger protocol (Sanger et al., 1977) at Firstbase Company, Malaysia.

\section{Data analysis}

Sequences were edited and aligned using MEGA 6.06 (Molecular Evolutionary Genetic Analysis) (Tamura et al., 2013). After editing and aligning, DNA sequences were trimmed to reduce the negative impact from alien oligonucleotide sequences in the read end (Criscuolo and Brisse, 2013). The aligned data was matched in the NCBI (National Center for Biotechnology Information) search system using BLAST (Basic Local Alignment Search Tool) accessed 
via the website http://blast.ncbi.nlm.nih.gov, and percent identity and query cover noted. The percent identity is a quantity that explains how similar the query sequence is to the target sequence (number of characters in each sequence that are identical). The higher the percent identity is, the more significant the match. The query cover is a number that describes how much of the query sequence is covered by the target sequence. All sequences were deposited in BOLD systems under the project "DNA barcoding of Clavulariidae in Indonesia" (http://www.boldsystems. org). Species delineation by determining the number of Operational Taxonomic Units (OTUs) based on pairwise sequence distances between individuals within the dataset was applied with the Automatic Barcode Gap Discovery (ABGD) tool (Puillandre et al., 2012).

Phylogenetic tree reconstruction with Neighbor-Joining and Maximum Likelihood was performed in MEGA 6.06. Re-sampling characteristics used non-parametric bootstrapping with 1000 replications per bootstrap to visualize the branch in
MEGA 6.06. For DNA evolution, there are many models that can be used to reconstruct a phylogenetic relationship. Initially, the best-fitting model was searched by using Find Best DNA/Protein $(\mathrm{ML})$ in the MEGA 6.06 Program. The Tamura 3parameter model was used to select the best-fitting model based on maximum likelihood. To analyze genetic distance, the Neighbor-Joining (NJ) method and a Kimura 2-parameter model were used. 1000 replicates per bootstrap were used, and out-grouped with the species Eunicea flexuosa (accession number: KC310539.1) to root the trees.

\section{Results and Discussion}

The molecular identification (Table 2-) confirmed that all tissue samples belonged to Clavularia inflata, with a high percent identity (92\% $100 \%)$ and query cover of $95-100 \%$. Most of the percent identity was between 99-100\%; only four of the 25 samples (from Kon and Bontang) had a percent identity value below $99 \%$.

Table 2. Quality of molecular identification of sample sequences collected from the different sampling sites, showing ID numbers used in BLAST searches on NCBI, maximum identification (\%), and query cover (\%). All samples were identified as belonging to Clavularia inflata.

\begin{tabular}{|c|c|c|c|}
\hline ID Number & Sampling sites & Max. Ident (\%) & $\begin{array}{ll}\begin{array}{l}\text { Query } \\
(\%)\end{array} & \text { Cover } \\
\end{array}$ \\
\hline ITK SC ANAMBAS 02 & Anambas & 99 & 99.84 \\
\hline ITK SC ANAMBAS 01 & Anambas & 99 & 100 \\
\hline ITKSCNAT17 & Natuna & 100 & 100 \\
\hline ITKSCNAT13 & Natuna & 100 & 100 \\
\hline ITKTLSC23 & Tanjung Lesung & 99 & 100 \\
\hline ITKTLSCO9 & Tanjung Lesung & 99 & 100 \\
\hline ITKPJGSC10 & Kep Seribu & 99 & 100 \\
\hline ITKPJGSC09 & Kep Seribu & 99 & 100 \\
\hline ITK MDR SC 05 & Madura & 99 & 100 \\
\hline KANG 01 & Kangean & 99 & 100 \\
\hline KANG 02 & Kangean & 99 & 100 \\
\hline ITK LMBK SC 1_12 & Lombok & 99 & 100 \\
\hline ITK LMBK SC 1_06 & Lombok & 99 & 100 \\
\hline ITK BON SC 32 & Bontang & 94 & 99.46 \\
\hline ITK BON SC 35 & Bontang & 94 & 99.46 \\
\hline ITK MER SC 03 & Manado & 100 & 99.49 \\
\hline ITK MER SC 02 & Manado & 100 & 99.49 \\
\hline ITK WKT SC 09 & Wakatobi & 99 & 95.76 \\
\hline ITK MER SC 10 & Manado & 100 & 99.49 \\
\hline ITK MOR SC 05 & Morotai & 100 & 100 \\
\hline ITK MOR SC 07 & Morotai & 99 & 100 \\
\hline ITK KON SC 07 & Kon & 93 & 99.82 \\
\hline ITK SC KON 16 & Kon & 92 & 100 \\
\hline ITK MTB SC 48 & Maluku Tenggara Barat & 99 & 99.96 \\
\hline ITK MTB SC 50 & Maluku Tenggara Barat & 99 & 99.96 \\
\hline
\end{tabular}


Table 3. Summary statistics for nucleotide frequency distribution of Clavularia inflata sequences $(n=25)$ across the 13 sampled Indonesian coral reef locations

\begin{tabular}{llll}
\hline Nucleotide base & Min & Mean & Max \\
\hline C\% & 16.24 & 16.35 & 17.29 \\
G\% & 18.78 & 19.31 & 20.47 \\
A\% & 28.60 & 30.22 & 30.63 \\
T\% & 33.28 & 34.12 & 34.52 \\
\hline
\end{tabular}

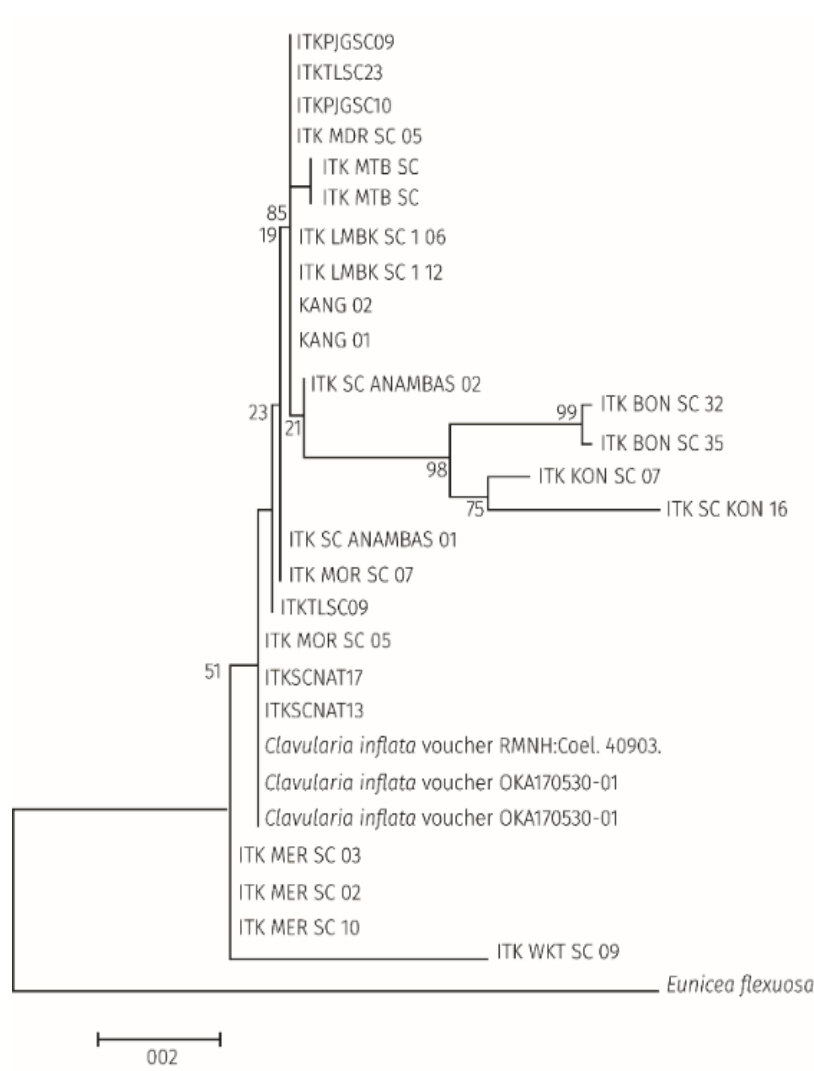

(a)

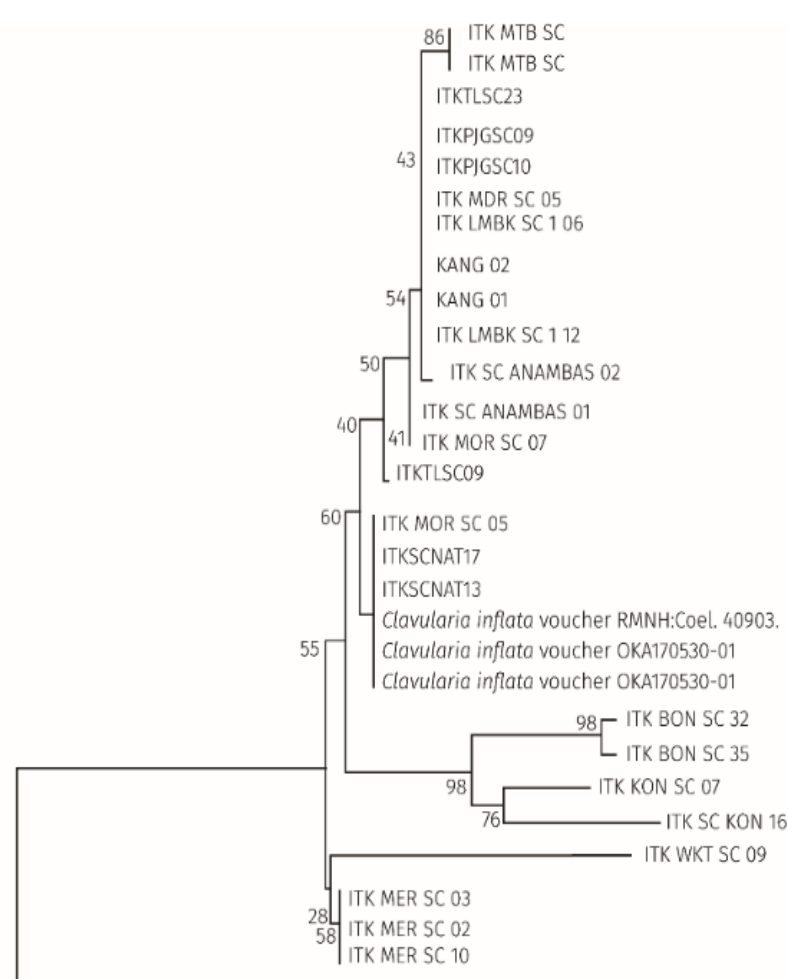

$\longmapsto 001$

(b)

Figure 2. Phylogenetic tree of 25 sequences Clavularia inflata constructed using (A) Neighbor Joining (NJ) and (B) the Maximum Likelihood method with Kimura 2 Parameter model, bootstrap value 1000x.

The results of genetic analysis confirmed the entire study samples as belonging to Clavularia inflata. The phylogenetic trees constructed from the 25 nucleotide base chain sequences derived from the samples using Neighbor Joining and Maximum Likelihood show two large clades (Figure 2.).

The 25 sequences generated from Clavularia inflata show a nucleotide composition of $\mathrm{A}=30.22 \%$, $\mathrm{T}=34.12 \%, \mathrm{C}=16.35 \%, \mathrm{G}=19.31 \%$ (Table 3.). The nucleotide composition of all sequences was related to the genetic distances between individuals. Sample ITK WKT SC 09 from Wakatobi had the highest genetic distance to other samples in this study (Table 4.). The number of OTUs generated by ABGD based on the Kimura-2-parameter model (K2P) varied from
2 to 5 (Figure 3.). The initial partition at a prior intraspecific divergence $(P)=0.001-0.007$ produced 3 OTUs, while a Recursive partition at a prior intraspecific divergence $(P)=0.0129-0.1$ produced 2 OTUs.

All samples used in this study could be unequivocally identified as belonging to $C$. inflata by means of molecular tools. The use of molecular identification for soft corals has become a regular tool for describing or determining new species (Benahayu and McFadden, 2011). Furthermore, the results of molucular identification can also provide support in delineating boundaries between species that have not been previously revealed (France, 2007; McFadden et al., 2009). 
DNA sequences of $C$. inflata are still rarely found in genetic databases. For example, there are only eight mtMuts sequences $\mathrm{n}$ GenBank, each originating from either Okinawa/Japan or Palau. As this study has contributed an additional 25 Clavularia inflata sequences to a database that is freely available to the public, the results from this study can enrich the information base for barcoding of soft corals elsewhere because the samples were taken across a range of nearly $4000 \mathrm{~km}$ throughout Indonesia. The available sequences will also be beneficial for DNA barcoding identification. Additional information from this research can help in studying and deciphering complexities in the clavulariidae family in particular or soft corals in general.

Information from ABGD shows that there are two major groups of $C$. inflata found in Indonesia. The two groups were also seen in the phylogenetic tree, namely the group from the first clade originating from Wakatobi and Manado and the second clade from samples originating from Tanjung Lesung, Kepulauan Seribu, Maluku Tenggara Barat, Lombok, Madura, Anambas, Bontang, Kon, Natuna, Kangean and Morotai. Currents are one of the factors that causes genetic similarity in the same species in different locations (Knittweis et al., 2009). Wakatobi and Manado are passed by the ITF which moves through the Pacific, passing by Manado and then to the south via Wakatobi. This is likely responsible for the higher genetic closeness at these compared to other locations. The observation of two major groups indicates the possibility of the presence of cryptic species in this type. The potential for identification of cryptic species and genera using mtDNA barcodes is still high, as evidenced by the outcome of biodiversity studies in the Red Sea and elsewhere (McFadden et al., 2006a, 2009). Previous research using visual tools identified C. inflata var. Iuzoniana May 1899 (Roxas, 1933) in the Philippines, which has different morphological characteristics from Clavularia inflata. However, genetic information about the variant is not yet available, so this study cannot be compared genetically. The hypothetical existence of two species in this study region could eventually be confirmed by using other primers on different loci of DNA. The species partition hypothesis needs further exploration, such as the inclusion of more than one locus as additional information, since a single locus is not strong enough to develop reliable species hypotheses (Puillandre et al., 2012). In a previous study of Alcyanium, interspecific genetic distances were twice greater for msh1 than COI, each marker identified similar numbers of species, and the extended $\mathrm{COI}+$ igr1 + msh1 barcode more effectively discriminated sister taxa (McFadden et al., 2011).

DNA barcoding is an important tool to support the management of biological resources, one of which are soft corals. As soft corals are among the species that are difficult to identify morphologically, DNA barcoding data are very valuable for identifying them. Studies that combine molecular characterstate data (i.e. barcodes) with traditional morphological taxonomic approaches have greatly improved our understanding of species boundaries

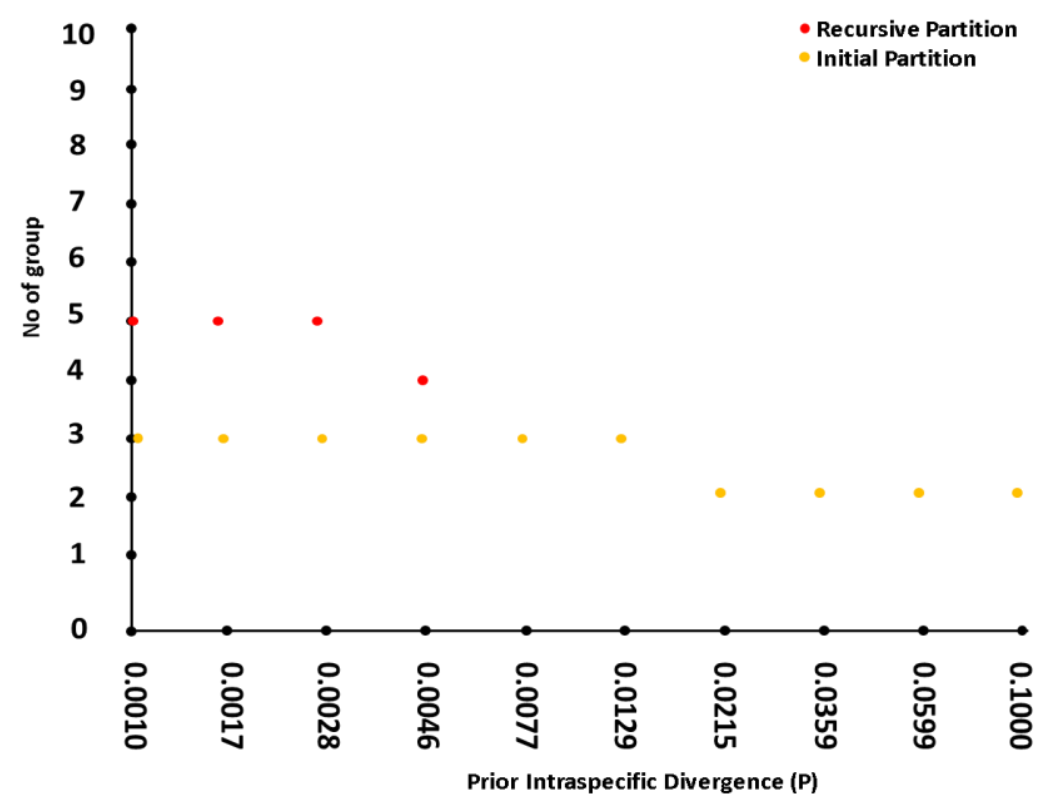

Figure 4. The number of genetically distinct Operational Taxonomic Units (OTUs) according to the recursive partition (red dots) and initial partition (yellow dots) at a prior intraspecific divergence value generated by Automatic Barcode Gap Discovery (ABGD) based on the Kimura-2-parameter model (K2P). 
ILMU KELAUTAN: Indonesian Journal of Marine Sciences March 2022 Vol 27(1): 1-12

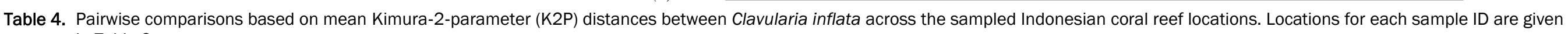
in Table 2

\begin{tabular}{|c|c|c|c|c|c|c|c|c|c|c|c|c|c|c|c|c|c|c|c|c|c|c|c|c|c|}
\hline Sample Id & 1 & $\underline{2}$ & $\underline{3}$ & $\underline{4}$ & $\underline{5}$ & $\underline{6}$ & $\underline{7}$ & $\underline{8}$ & $\underline{9}$ & $\underline{10}$ & $\underline{11}$ & $\underline{12}$ & $\underline{13}$ & $\underline{14}$ & $\underline{15}$ & $\underline{16}$ & $\underline{17}$ & $\underline{18}$ & $\underline{19}$ & $\underline{20}$ & $\underline{21}$ & $\underline{22}$ & $\underline{23}$ & $\underline{24}$ & $\underline{25}$ \\
\hline \multicolumn{26}{|l|}{ ITK SC ANAMBAS 02} \\
\hline ITK SC ANAMBAS 01 & 0,003 & & & & & & & & & & & & & & & & & & & & & & & & \\
\hline ITK BON SC 32 & 0,038 & 0,038 & & & & & & & & & & & & & & & & & & & & & & & \\
\hline ITK BON SC 35 & 0,038 & 0,038 & 0,003 & & & & & & & & & & & & & & & & & & & & & & \\
\hline KANG 01 & 0,002 & 0,002 & 0,04 & 0,04 & & & & & & & & & & & & & & & & & & & & & \\
\hline KANG 02 & 0,002 & 0,002 & 0,04 & 0,04 & 0 & & & & & & & & & & & & & & & & & & & & \\
\hline ITK KON SC 07 & 0,03 & 0,033 & 0,031 & 0,031 & 0,031 & 0,031 & & & & & & & & & & & & & & & & & & & \\
\hline ITK SC KON 16 & 0,042 & 0,042 & 0,04 & 0,04 & 0,044 & 0,044 & 0,03 & & & & & & & & & & & & & & & & & & \\
\hline ITK LMBK SC 12 & 0,002 & 0,002 & 0,04 & 0,04 & 0 & 0 & 0,031 & 0,044 & & & & & & & & & & & & & & & & & \\
\hline ITK LMBK SC 06 & 0,002 & 0,002 & 0,04 & 0,04 & 0 & 0 & 0,031 & 0,044 & 0 & & & & & & & & & & & & & & & & \\
\hline ITK MDR SC 05 & 0,002 & 0,002 & 0,04 & 0,04 & 0 & 0 & 0,031 & 0,044 & 0 & 0 & & & & & & & & & & & & & & & \\
\hline ITK MER SC 03 & 0,012 & 0,009 & 0,033 & 0,033 & 0,01 & 0,01 & 0,042 & 0,047 & 0,01 & 0,01 & 0,01 & & & & & & & & & & & & & & \\
\hline ITK MER SC 02 & 0,012 & 0,009 & 0,033 & 0,033 & 0,01 & 0,01 & 0,042 & 0,047 & 0,01 & 0,01 & 0,01 & 0 & & & & & & & & & & & & & \\
\hline ITK MOR SC 05 & 0,007 & 0,003 & 0,038 & 0,038 & 0,005 & 0,005 & 0,037 & 0,042 & 0,005 & 0,005 & 0,005 & 0,005 & 0,005 & & & & & & & & & & & & \\
\hline ITK MOR SC 07 & 0,003 & 0 & 0,038 & 0,038 & 0,002 & 0,002 & 0,033 & 0,042 & 0,002 & 0,002 & 0,002 & 0,009 & 0,009 & 0,003 & & & & & & & & & & & \\
\hline ITK MTB SC 48 & 0,005 & 0,005 & 0,044 & 0,044 & 0,003 & 0,003 & 0,035 & 0,047 & 0,003 & 0,003 & 0,003 & 0,014 & 0,014 & 0,009 & 0,005 & & & & & & & & & & \\
\hline ITK MTB SC 50 & 0,005 & 0,005 & 0,044 & 0,044 & 0,003 & 0,003 & 0,035 & 0,047 & 0,003 & 0,003 & 0,003 & 0,014 & 0,014 & 0,009 & 0,005 & 0 & & & & & & & & & \\
\hline ITK SCNAT17 & 0,007 & 0,003 & 0,038 & 0,038 & 0,005 & 0,005 & 0,037 & 0,042 & 0,005 & 0,005 & 0,005 & 0,005 & 0,005 & 0 & 0,003 & 0,009 & 0,009 & & & & & & & & \\
\hline ITK SCNAT13 & 0,007 & 0,003 & 0,038 & 0,038 & 0,005 & 0,005 & 0,037 & 0,042 & 0,005 & 0,005 & 0,005 & 0,005 & 0,005 & 0 & 0,003 & 0,009 & 0,009 & 0 & & & & & & & \\
\hline ITK PJGSC10 & 0,002 & 0,002 & 0,04 & 0,04 & 0 & 0 & 0,031 & 0,044 & 0 & 0 & 0 & 0,01 & 0,01 & 0,005 & 0,002 & 0,003 & 0,003 & 0,005 & 0,005 & & & & & & \\
\hline ITK PJGSC09 & 0,002 & 0,002 & 0,04 & 0,04 & 0 & 0 & 0,031 & 0,044 & 0 & 0 & 0 & 0,01 & 0,01 & 0,005 & 0,002 & 0,003 & 0,003 & 0,005 & 0,005 & 0 & & & & & \\
\hline ITK TLSC23 & 0,002 & 0,002 & 0,04 & 0,04 & 0 & 0 & 0,031 & 0,044 & 0 & 0 & 0 & 0,01 & 0,01 & 0,005 & 0,002 & 0,003 & 0,003 & 0,005 & 0,005 & 0 & 0 & & & & \\
\hline ITK TLSCO9 & 0,005 & 0,002 & 0,04 & 0,04 & 0,003 & 0,003 & 0,035 & 0,044 & 0,003 & 0,003 & 0,003 & 0,007 & 0,007 & 0,002 & 0,002 & 0,007 & 0,007 & 0,002 & 0,002 & 0,003 & 0,003 & 0,003 & & & \\
\hline ITK WKT SC 09 & 0,048 & 0,044 & 0,066 & 0,066 & 0,046 & 0,046 & 0,073 & 0,073 & 0,046 & 0,046 & 0,046 & 0,038 & 0,038 & 0,044 & 0,044 & 0,049 & 0,049 & 0,044 & 0,044 & 0,046 & 0,046 & 0,046 & 0,046 & & \\
\hline ITK MER SC 10 & 0,012 & 0,009 & 0,033 & 0,033 & 0,01 & 0,01 & 0,042 & 0,047 & 0,01 & 0,01 & 0,01 & 0 & 0 & 0,005 & 0,009 & 0,014 & 0,014 & 0,005 & 0,005 & 0,01 & 0,01 & 0,01 & 0,007 & 0,038 & \\
\hline
\end{tabular}


and intracellular relationships and have identified new, diagnostic morphological character states useful for field identification in several speciose and ecologically important genera of octocorals (McFadden et al., 2006a, 2009; France, 2007). C. inflata is known to possess biomedical properties (Sheu et al., 2019) but is also traded as an ornamental animal for marine aquaria (Wabnitz et al., 2003). The data presented here can later be used as a basis for tracking the sources of invasive origin or introduced species in other regions. For example, observations in Brazil have found Clavularia cf. viridis soft corals invading benthic substrate. The presence of these invertebrates is assumed to originate from the ornamental aquarium trade sourced from the Indo-Pacific region (Mantelatto et al., 2018).

\section{Conclusion}

Molecular analysis confirmed all samples as belonging to $C$. inflata. The combination of different genetic tools in this study suggests the presence of cryptic species in this type. Further studies using additional molecular markers and morphological characteristics are suggested to further explore the possibility of cryptic species.

\section{Acknowledgement}

This study was funded by the Ministry of Research, Technology and Higher Education of the Republic of Indonesia in 2018 under the scheme "Penelitian Disertasi Doctor (PDD)". This study was supported by the Marine Biodiversity and Biosystematics Laboratory, Department of Marine Science and Technology, IPB University, Bogor, West Java, Indonesia. This paper is supported by USAID through Sustainable Higher Education Research Alliances (SHERA) Program- Animal Biotechnology and Coral Reef Fisheries (ANBIOCORE). The authors would like to thank Miss Nurlita Putri Anggraeni for technical laboratory support.

\section{References}

Abdullah, A., Nurilmala, M., Muttaqin, E. \& Yulianto, I., 2020. DNA-based analysis of shark products sold on the Indonesian market towards seafood labelling accuracy program. Biodiversitas, 21(4): 1385-1390. https://doi.org/10.13057/biodiv/ d210416

Ackiss, A.S., Pardede, S., Crandall, E.D., AblanLagman, M.C.A., Barber, P.H. Ambariyanto, A. \& Carpenter, K.E., 2013. Pronounced genetic structure in a highly mobile coral reef fish, Caesio cuning, in the Coral Triangle. Mar. Ecol. Prog. Ser., 480: 185-197.
Aini, N.K., Erwyansyah, E., Kurnia, R., Butet, N.A., Mashar, A., Zairion, Z., Funch, P., Madduppa, H. \& Wardiatno, Y. 2020. Two morphotypes of trispine horseshoe crab, Tachypleus tridentatus (Leach, 1819) (Xiphosura Limulidae) in Indonesia and implications for species identification. Biodiversity, 11(2): 535-540. https://doi.org/10.31396/Biodiv.Jour.2020.11. 2.535 .540

Anzani L., Madduppa, H., Nurjaya, I.W. \& Dias, P.J. 2019. Short communication: Molecular identification of white sea squirt Didemnum sp. (tunicata, ascidiacea) colonies growing over corals in Raja Ampat Islands, Indonesia. Biodiversitas. 20(3): 636-642. https://doi.org/ 10.13057/ biodiv/d200304

Bayer F.M. 1973. Colonial organization in octocorals. In: Brodman R.S., A.H. Cheetman \& W.A. Oliver Jr. (Ed). Animal colonies development and function through time. Dowden, Hutchinson and Ross. Pennsylvania. P: 69-93

Bastidas, C., Benzie, J. \& Fabricius, K 2002. Genetic differentiation among populations of the brooding soft coral Clavularia koellikeri on the Great Barrier Reef. Coral Reefs, 21(3): 233-241. https://doi.org/10.1007/s00338-002-0236-7

Benayahu Y. \& McFadden, C.S. 2011. A new genus of soft coral of the family Alcyoniidae (Cnidaria, Octocorallia) with re-description of a new combination and description of a new species. ZooKeys. 84: 1-11. https://doi.org/10.3897/zoo keys.84.7 81

Bingpeng, X., Heshan, L., Zhilan, Z., Chunguang, W., Yanguo, W. \& Jianjun, W. 2018. DNA barcoding for identification of fish species in the Taiwan Strait. Plos One. 13: e0198109. https://doi. org/10.1371/journal.pone.019 8109

Criscuolo A. \& Brisse, S. 2013. Alien Trimmer: a tool to quickly and accurately trim off multiple short contaminant sequences from high-throughput sequencing reads. Genomics. 102(5-6): 500506.https://doi.org/10.1016/j.ygeno.2013.07. 011

Dai, C.F. 1988. Coral communities of southern Taiwan. Proc 6th Intl Coral Reef Symp. 2: 647652.

DeBoer, T.S., Subia, M.D., Ambariyanto, A., Erdmann, M.V., Kovitvongsa, K. \& Barber, P. H. 2008. Phylogeography and limited genetic connectivity in the endangered boring giant clam across the Coral Triangle. Conserv. Biol.,22(5): 1255-1266. 
Dinesen, Z.D. 1983. Patterns in the distribution of soft corals across the central Great Barrier Reef. Coral Reefs. 1: 229-236. https://doi.org/10.10 07/BF0030 4420

Dray S. \& Dufour, A.B. 2007. The ade4 package: Implementing the duality diagram for ecologists. J. Stat. Softw., 22: 1-20. https://doi.org/10.18 $637 /$ jss.v022.i04.

Etikan I., Musa, S.A. \& Alkassim, R.S. 2016. Comparison of convenience sampling and purposive sampling. Am. J. Theor. Appl. Stat., 5(1): 1-4. doi: 10.11648/j.ajtas.20160501.11

Fadli, N., Nor, S.A.M., Othman, A.S., Sofyan, H. \& Muchlisin, Z.A. 2020. DNA barcoding of commercially important reef fishes in Weh Island, Aceh, Indonesia. PeerJ. 8: e9641 https://doi.org/10.7717/peerj.9641

Fabricius K.E. 1997. Soft coral abundance on the central Great Barrier Reef: effects of Acanthaster planci, space availability, and aspects of the environment. Coral Reefs. 16: 159-167. https://doi.org/10.1007/s00338005 0070

Fabricius K.E. \& Alderslade, P. 2001. Soft corals and sea fans: a comprehensive guide to the tropical shallow water genera of the central-west Pacific, the Indian Ocean and the Red Sea. Australian Institute of Marine Science, Townsville.

France, S.C. 2007.Genetic analysis of bamboo corals (Cnidaria: Octocorallia: Isididae): does lack of colony branching distinguish Lepidisis from Keratoisis. Bull. Mar. Sci., 81: 323-333.

Hazeri, G., Rahayu, D.L., Subhan, B., Sembiring, A., Anggoro, A.W., Ghozali, A.T. \& Madduppa, H.H. 2019. Latitudinal species diversity and density of cryptic crustacean (brachyura and anomura) in micro-habitat autonomous reef monitoring structures across Kepulauan Seribu, Indonesia. Biodiversitas. 20(5): 1466-1474. https://doi. org/10.130 57/biodiv/d200540

Hebert, P.D., Cywinska, A., Ball, S.L. \& DeWaard, J.R. 2003. Biological identifications through DNA barcodes. Proc. Royal Soc. B. 270: 313-321. https://doi.org/10.1098/rspb.2002.2218

Hubert N., E. Delrieu-Trottin, J-O. Irisson, C. Meyer \& S. Planes. 2010. Identifying coral reef fish larvae through DNA barcoding: a test case with the families Acanthuridae and Holocentridae. Mol. Phylogenet. Evol., 55: 1195-1203. https://doi. org/10.1016/j.ympev.2010.02.023
Hoeksema B.W. 2007. Delineation of the IndoMalayan centre of maximum marine biodiversity In: Willem Renema (Eds.), Biogeography, Time, and Place: Distributions, Barriers, and Islands Topics in Geobiology. 29: 117-178. https://doi. org/10.1007/978-1-4020-6374-9_5

Hosein, F.N., Austin, N., Maharaj, S., Johnson, W., Rostant, L., Ramdass, A.C. \& Rampersad, S.N. 2017. Utility of DNA barcoding to identify rare endemic vascular plant species in Trinidad. Ecol. Evol., 7(18): 7311-7333. https://doi.org/10. 1002/ece3.3220.

Jefri, E., Zamani, N.P., Subhan, B. \& Madduppa, H.H. 2015. Molecular phylogeny inferred from mitochondrial DNA of the grouper Epinephelus spp. in Indonesia collected from the local fish market. Biodiversitas. 16: 254-263. https://doi. org/ 10.13 057/biodiv/d160221

Kholilah N., Afiati, N. \& Subagiyo. 2021. Characterizationof Some Commercially Important Octopus (Mollusca: Cephalopoda) from Indonesian Waters using Mitochondrial DNA Cytochrome Oxidase SubUnit I (MtDNA COI). IImu Kelautan: Indonesia Journal of Marine Sciences. 26: 17-26. https://doi.org/10.1471 0/ik.ijms. 26.1.17-26

Kusuma A.B., Bengen, D.G., Madduppa, H., Subhan, B. \& Arafat, D. 2016. Genetic diversity of soft coral Sarcophyton trocheliophorum in Java, Nusa Tenggara and Sulawesi Sea populations . J. Enggano. 1(1): 89-96. https://doi.org/10. 31186/jenggano.1.1.89-96

Knittweis, L., Kraemer, W.E., Timm, J. \& Kochzius, M., 2009 Genetic structure of Heliofungia actiniformis (Scleractinia: Fungiidae) populations in the Indo-Malay Archipelago: implications for live coral trade management efforts. Conserv. Genet. 10(1): 241-249. https://doi.org/10.1007/s10592-008-9566-5

Lau Y.W., Stokvis, F.R., Imahara, Y. \& Reimer, J.D. 2019. The stoloniferous octocoral, Hanabira yukibana, gen. nov., sp. nov., of the southern Ryukyus has morphological and symbiont variation. Contributions to Zoology. 88(1): 5477. https://doi.org/10.1163/18759866-2019 1355

Lepard, A.B. 2003. Analysis of variation in the mitochondrial encoded $\mathrm{MSH} 1$ in the genus Leptogorgia (Cnidaria: Octocorallia) and implications for population and systematics studies. M.S. thesis, University of Charleston, Charleston, SC. 
Madduppa H., Cahyani, N.K.D., Anggoro, A.W., Subhan, B., Jefri, E., Sani, L.M.I., Arafat, D., Akbar, N. \& Bengen, D.G. 2021. eDNA metabarcoding illuminates species diversity and composition of three phyla (chordata, mollusca and echinodermata) across Indonesian coral reefs. Biodivers. Conserv. 30(11): 3087-3114. https://doi.org/10.1007/s10531-021-02237-0

Madduppa H., Putri A.S., Wicaksono R.Z., Subhan B, Akbar N., Ismail F., Arafat D., Prabuning D., Sani L.M.I., Srimariana E.S., Baksir A. 2020. Morphometric and DNA Barcoding of endemic Halmaheran walking shark (Hemiscyllium halmahera, Allen, 2013) in North Maluku, Indonesia: Morphogenetic of endemic Halmaheran walking shark. Biodiversitas, 21(7): 3331-3343. https://doi.org/10.13057/biodiv/ d210757

Madduppa, H., Subhan, B., Anggraini, N.P., Fadillah, R. \& Tarman, K. 2017. Short communication: Dna barcoding reveals vulnerable and not evaluated species of sea cucumbers (Holothuroidea and Stichopodidae) from Kepulauan Seribu reefs, Indonesia. Biodiversitas. 18(3): 893-898. https://doi.org/ $10.13057 /$ biodiv/d180305

Madduppa H., Timm, J. \& Kochzius, M. 2014. Interspecific, spatial and temporal variability of self-recruitment in Anemonefishes. Plos One. 9(2): 1-13. https://doi.org/10.1371/journal.po ne.0090648

Madduppa, H.H., Bahri, S., Subhan, B., Anggraini, N.P., Ohoiulun, H., Abdillah, T., Arafat, D., Santoso, P. \& Sangadji, I.M. 2019. DNA barcoding of sea turtles (Dermochelyidae and Cheloniidae) and its protocol using different tissues quality: Implication to conservation managers. IOP Conf. Ser. Earth Environ. Sci., 278(1): 012041. https://doi.org/10.1088/17 55-1315/278/1/012041

Manuputty A.E.W. 1996. Soft coral is one of the constituents of coral reefs. Oceana. 11 (4):131141 (in Bahasa Indonesia)

Manuputty A.E.W. 2010, Distribution of soft coral, genus Sinularia May, 1898 (Octocorallia, Alcyonacea) on Derawan islands, East Kalimantan. Oseanologi dan Limnologi di Indonesia. 36: 211-225. (in Indonesian)

Manuputty A.E.W. \& van Ofwegen, L.P. 2007. The genus Sinularia (Octocorallia: Alcyonacea) from Ambon and Seram (Moluccas, Indonesia). Zool. Med. Leiden. 81: 187-216.

Manuputty AEW. 2002, Soft coral Indonesian waters, LIPI Pusat Penelitian Oseanografi. Jakarta. 91 pp

Mantelatto, M.C., da Silva, A.G., dos Santos Louzada, T., McFadden, C.S. \& Creed, J.C., 2018. Invasion of aquarium origin soft corals on a tropical rocky reef in the southwest Atlantic, Brazil. Mar. Poll. Bull., 130: 84-89. https://doi.org/10.1016/j. marpolbul.20 18.03.014

McFadden, C.S., France, S.C., Sánchez, J.A. \& Alderslade, P., 2006a. A molecular phylogenetic analysis of the Octocorallia (Cnidaria: Anthozoa) based on mitochondrial protein-coding sequences. Mol. Phylogenet. Evol., 41: 513-527. https://doi.org/10.1016/j.ympev.2006.0 6.010

McFadden, C.S., Alderslade, P., Van Ofwegen, L.P., Johnsen, H. \& Rusmevichientong, A. 2006b. Phylogenetic relationships within the tropical soft coral genera Sarcophyton and Lobophytum (Anthozoa, Octocorallia). Invertebr. Biol., 125: 288-305. https://doi.org/10.1111/j.1744-741 0.2006.00 070.x

McFadden C.S. \& van Ofwegen. L.P. 2012. Stoloniferous octocorals (Anthozoa, Octocorallia) from South Africa, with descriptions of a new family of Alcyonacea, a new genus of Clavulariidae and a new species of Cornularia (Cornulariidae). Invertebr. Syst. 26: 331-356. https://doi.org/10.1071/IS12035

McFadden, C.S., Van Ofwegen, L.P., Beckman, E.J., Benayahu, Y. \& Alderslade, P.. 2009. Molecular systematics of the speciose Indo-Pacific soft coral genus, Sinularia (Anthozoa: Octocoralia). Invertebr. Biol., 128: 303-323. https://doi.org/ 10.1111/j.1744-7410.2009.00179.x

McFaddrn, C.S., Benayahu, Y., Pante, E., Thoma, J.N., Nevarez, P.A. \& France, S.C.,. Limitations of mitochondrial gene barcoding in Octocorallia. Mol. Ecol. Res., 11: 19-31. https://doi.org/ 10.1111/j.1755-0998.2010.02875.x

McFadden, C.S., Reynolds, A.M. \& Janes, M.P., 2014. DNA barcoding of xeniid soft corals (Octocorallia: Alcyonacea: Xeniidae) from Indonesia: Species richness and phylogenetic relationships. System. Biodivers., 12: 247-257. https://doi. 
org/10.1080/ 14772000.2014.902866

Moore K.M., Alderslade, P. \& Miller, K.J. 2017. A taxonomic revision of Anthothela (Octocorallia: Scleraxonia: Anthothelidae) and related genera, with the addition of new taxa, using morphological and molecular data. Zootaxa, 4304(1): 1-212. https://doi.org/10.11646/zoota xa.4304.1.1

Prehadi, P., Sembiring, A., Kurniasih, E.M., Rahmad, R., Arafat, D., Subhan, B. \& Madduppa, H.H., 2015. DNA barcoding and phylogenetic reconstruction of shark species landed in Muncar fisheries landing site in comparison with Southern Java fishing port. Biodiversitas. 16: 5561. doi: $10.13057 /$ biodiv/d160107

Puillandre, N., Lambert, A., Brouillet, S. \& Achaz, G.J.M.E., 2012. ABGD, Automatic Barcode Gap 543 Discovery for primary species delimitation. Mol. Ecol. 21: 1864-544. https://doi.org/ 10.1111/j.1365-294X. 2011.05239.x

Quattrini, A.M., Etnoyer, P.J., Doughty, C., English, L., Falco, R., Remon, N., Rittinghouse, M. \& Cordes, E.E., 2014. A phylogenetic approach to octocoral community structure in the deep Gulf of Mexico. Deep Sea Res. Part II Top. Stud. Oceanogr., 99: 92-102. https://doi.org/10.1016/j.dsr2.2013. 05.027

Rao, C.R. 1964. The use and interpretation of principal component analysis in applied research. Sankhyā, 26: 329-359.

Riegl B., Schleyer, M.H., Cook, P.J. \& Branch, G.M. 1995. Structure of Africa's southernmost coral communities. Bull. Mar. Sci. 56: 676-691.

Roxas, H.A. 1933. Philippine Alcyonaria. The families Cornulariidae and Xeniidae. Philippine J. Sci. 50: 49-110

Saleky D., Setyobudiandi, I., Toha, H.A., Takdir, M. \& Madduppa, H. 2016. Length-weight relationship and population genetic of two marine gastropods species (Turbinidae: Turbo sparverius and Turbo bruneus) in the Bird Seascape Papua, Indonesia. Biodiversitas. 17: 208-217. https://doi.org/10.13057/biodiv/d1 70130

Sanger F., Nicklen, S. \& Coulson, A.R. 1977. DNA sequencing with chain-terminating inhibitors.
Proc Natl Acad Sci. 74(12): 5463-5467. https://doi.org/10.1073/pnas.74.12.5463

Schenk A., 1896. Clavulariiden, Xeniiden und Alcyoniiden von Ternate. Abhandl. Senckenb. Naturf. Ges., Ed. 23: 41-80. https://doi.org/10. 5962/bhl.title.9164

Sembiring, A., Pertiwi, N.P.D., Mahardini, A., Wulandari, R., Kurniasih, E.M., Kuncoro, A.W., Cahyani, N.D., Anggoro, A.W., Ulfa, M., Madduppa, H. \& Carpenter, K.E., 2015. DNA barcoding reveals targeted fisheries for endangered sharks in Indonesia. Fish. Res.. 164: 130-134. https://doi.org/10.1016/j.fish res.2014. 11.003

Sheu, J.H., Peng, B.R., Fang, L.S., Hwang, T.L., Su, J.H., Wu, Y.C. \& Sung, P.J. 2019 Hydroperoxyditerpenoids from Octocorals. Isr. J. Chem. 59: 403-413. https://doi.org/10.1002/ijch.20190 0011.

Tamura, K., Stecher, G., Peterson, D., Filipski, A. \& Kumar, S. 2013. Mega 5: Molecular Evolution Genetics Analysis Version 6.0. Mol. Biol. Evo. 30: 2725-2729. https://doi.org/10.1093/molbev/ mst197

Toha, A.H.A., Dailami, M., Anwar, S., Setiawan, J.B., Jentewo, Y., Lapadi, I., Sutanto, S, Aryasari, R., Ambariyanto, A., Runtuboi, F. \& Madduppa, H. 2020. The genetic relationships and Indo-Pacific connectivity of whale sharks (Rhincodon typus) with particular reference to mitochondrial $\mathrm{COI}$ gene sequences from Cendrawasih Bay, Papua, Indonesia. Biodiversitas, 21(5): 2159-2171. https://doi.org/10.13057/biodiv/d210544

Tursch, B. \& Tursch, A. 1982. The soft coral community on a sheltered reef quadrat at Laing Island (Papua New Guinea). Mar. Biol. 68: 321332. https://doi.org/10.1007/BF00409597

Utinomi, H. 1953. Invertebrate fauna of the intertidal zone of the Tokara Islands. VI. Alcyonaria. Pub. Seto Mar. Biol. Lab. 3(2): 149-160, https://doi.org/10.5134/174473

Vogler, C., Benzie, J.A.H., Tenggardjaja, K., Ambariyanto, A., Barber, P.H. and Wörheide, G., 2013. Phylogeography of the crown-of-thorns starfish: genetic structure within the Pacific species. Coral Reefs, 32(2): 515-525.

Veron, J.E., Devantier, L.M., Turak, E., Green, A.L., 
ILMU KELAUTAN: Indonesian Journal of Marine Sciences March 2022 Vol 27(1):1-12

Kininmonth, S., Stafford-Smith, M. \& Peterson, N. 2009.Delineating the coral triangle. Galaxea, 11: 91-100. https://doi.org/10.3755/galaxea. 11.91
Wabnitz C., Taylor, M., Green, E. \& Razak, T. 2003. From Ocean to Aquarium. UNEP-WCMC, Cambridge, UK. 72 pp 